IRA-International Journal of Applied Sciences ISSN 2455-4499; Vol.11, Issue 01 (April 2018)

Pg. no. 1-8.

Institute of Research Advances

https://research-advances.org/index.php/IRAJAS

\title{
Land Suitability Evaluation for Rainfed Agriculture in Abu Hamra Area, South Darfur State, Sudan
}

\author{
Ibrahim, I. A. A ${ }^{1}$, Ibrahim, M.M.M ${ }^{2 \#}$, Sulieman, H. $A^{3}$, Elsheikh M.A ${ }^{4}$, Dafalla M S $S^{5}$, Ibrahim I. S \\ 1,2,3,4,5,6 Department of Soil and Environment Sciences, Faculty of Agriculture University of Khartoum, \\ Sudan.
}

\# corresponding author.

Type of Review: Peer Reviewed.

DOI: http://dx.doi.org/10.21013/jas.v11.n1.p1

How to cite this paper:

Ibrahim, I. A. A., Ibrahim, M.M.M., Sulieman, H. A., Elsheikh M.A., Dafalla M S., Ibrahim I. S. (2018). Land Suitability Evaluation for Rainfed Agriculture in Abu Hamra Area, South Darfur State, Sudan. IRA International Journal of Applied Sciences (ISSN 2455-4499), 11(1), 1-8. doi:http://dx.doi.org/10.21013/jas.v11.n1.p1

(C) Institute of Research Advances.

\section{$($ (c) $)$ BY-NO}

This work is licensed under a Creative Commons Attribution-Non Commercial 4.0 International License subject to proper citation to the publication source of the work.

Disclaimer: The scholarly papers as reviewed and published by the Institute of Research Advances (IRA) are the views and opinions of their respective authors and are not the views or opinions of the IRA. The IRA disclaims of any harm or loss caused due to the published content to any party.

Institute of Research Advances is an institutional publisher member of Publishers Inter Linking Association Inc. (PILA-CrossRef), USA. The institute is an institutional signatory to the Budapest Open Access Initiative, Hungary advocating the open access of scientific and scholarly knowledge. The Institute is a registered content provider under Open Access Initiative Protocol for Metadata Harvesting (OAI-PMH).

The journal is indexed \& included in CAS Source Index of Chemical Abstracts Service of American Chemical Society (USA), Index Copernicus (IC Value 85.27), WorldCat Discovery Service (USA), CrossRef Metadata Search (USA), WorldCat (USA), OCLC (USA), Open J-Gate (India), EZB (Germany) Scilit (Switzerland), Airiti (China), Bielefeld Academic Search Engine (BASE) of Bielefeld University, Germany, PKP Index of Simon Fraser University, Canada. 


\begin{abstract}
This study was carried out in Abu Hamra Area, south Darfur State (Latitude $12^{\circ} 26^{\prime}$ to $13^{\circ} 10^{\prime}$ E and longitude $24^{\circ} 24^{\prime}$ to $25^{\circ} 56^{\prime} N$ and), Sudan where the area falls in semi-arid climate. The study aimed to evaluate the land suitability for rainfed agriculture and to scan crop suitability. Through the analysis of satellite image and direct field observations, the study area was divided into non-cracking clay soil (unit A) classified as Sodic Haplocambid, alluvial soil (unit B) classified as Ustic Torrifluvent and loamy sand soil (unit C) classified as Typic Torripsamments. 46 soil samples were collected from 12 auger holes and 3 representative profiles, then analyzed for some physical and chemical properties which were matched with climatic factors and topographic features to define the requirements of rainfed crops, particularly Sorghum, Millet, Maize, Sesame, Groundnuts, Watermelon and Tomato. Duncan Multiple Range Test was used to determine significance of differences in soil properties within and among the three units. Results showed that the soils were non-saline, non-sodic (except unit A), calcareous to slightly calcareous and low in fertility. Results also indicated no significant differences among soil properties except for texture, salinity and sodicity. The soils were found to be marginally suitable (S3) for rainfed agriculture because of presence of fertility, drainage, organic matter, texture and sodicity limitations and unit B proved to be the best soils of the three units. For crop suitability, the soils of the three units had same suitability for some crops and differ for others.
\end{abstract}

Keywords: Abu Hamra; semi-arid climate; land suitability; crop suitability; rainfed agriculture.

\title{
INTRODUCTION
}

Soils are different in their morphological, physical, chemical, and mineralogical properties. These differences are due to variations in soils forming factors and sol forming processes, operating on different parent materials under different climatic, topographic and biological conditions over varying period of time (Soil Survey Staff, 1993). Different soil types support different land use and require different management options for sustainable productivity (Ogunkunle, 1986). Soil survey describes the characteristics of the soils in a given area (it relates properties to places) classifies the soil according to standard system of classification, plots the boundaries of the soils on maps and makes prediction about behavior of soils through land evaluation. The information collected in a soil survey helps in developing land use plans, evaluates and predicts the effect of land use on the environment (USDA, 1993). The land evaluation is usually conducted to determine land suitability for specific uses. The information obtained can be used for more realistic land use recommendation and present their constrain (FAO, 1995; Abdulkadir, 1998; Braimoh, 2000). The knowledge of soil physical and chemical properties is essential for analysis and mapping for crop and land suitability. It also offers management guidelines in order to promote a more sustainable use of the soil and natural resources.

The soil requirements and soil qualities are directly related to the crop yield performance. Soil suitability classifications are based on matching requirements for crops and soil qualities (FAO, 1995). In the Sudan very little (if any) work has been done in land evaluation in the rainfed areas and most of work done in such areas was on change detection in the Land Use/Land Capability (LU/LC) through time using Geographic Information System (GIS) and remote sensing techniques in Darfur State of the Sudan (including the present study area) most agriculture is rainfed agriculture. The crop production is typically traditional rainfed farming of small-scale farms. Some farmers practice winter farming, mostly vegetables production, using wadis $^{(1)}$ and small-scale irrigation techniques. However, crop performance results in low yields, reflecting unreliable rainfall, poor soils, low-input agriculture and low level of technology adoption. Therefore, this work aimed at evaluating land suitability for rainfed agriculture which could help in selecting proper crops and crops management practices. This might increase return of the farmer and improve the socio-economic status of the local population.

\section{MATERIALS AND METHODS}

Location of the study area

Abu Hamra $\left(\approx 17029\right.$ feddans ${ }^{2}$ including a rocky hilly area) area is located $95 \mathrm{~km}$ to the north from Nyala, Capital City of south Darfur State, Sudan. The area lies between longitudes $24^{\circ} 24^{\prime}$ and $25^{\circ} 56^{\prime} \mathrm{N}$ and latitudes $12^{\circ} 26^{\prime}$ and $13^{\circ} 10^{\prime}$ E. Figure (1) presents the location of the study area. The following three soil patterns, represent the physiographic positions, were found in the study area: non-cracking clay soil, alluvium and loamy sand soil. 


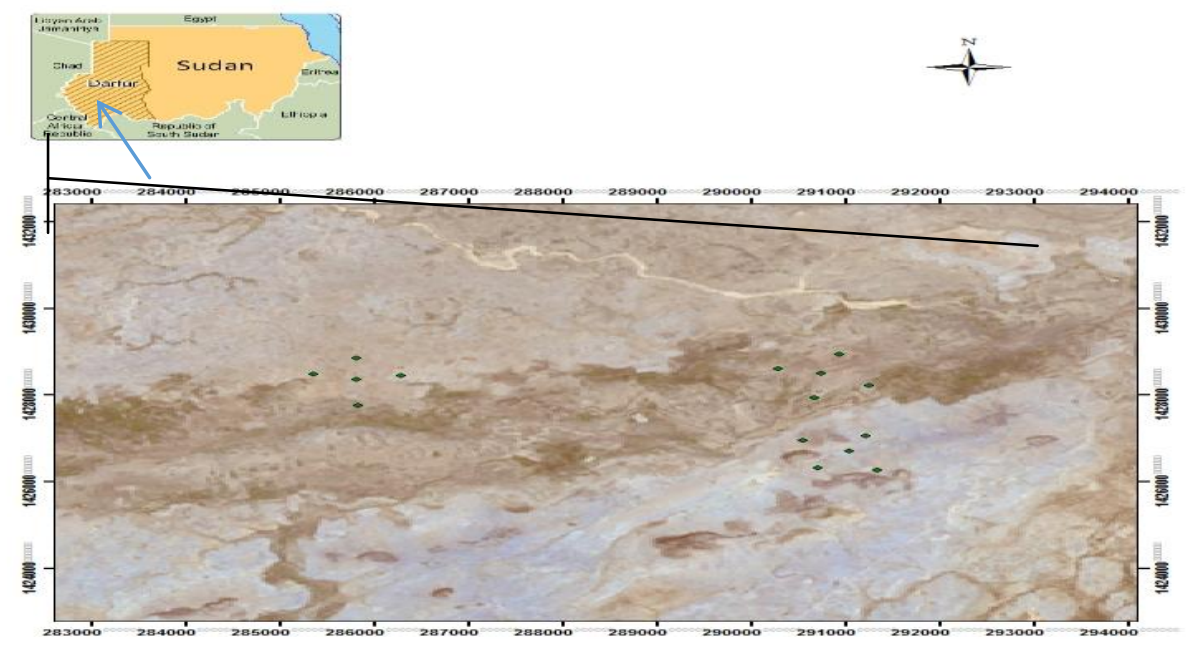

Figure 1 South Darfur Soil map including the study area

Table 1 shows the Extent (in feddans) and percentage of the three physiographic units in the study area.

Table 1: Extent (in feddans) and percentage of the three physiographic units in the study area

\begin{tabular}{|lcc|}
\hline Class & Area (Fed) & $\%$ \\
\hline Non-cracking soil & 6511.68 & 33 \\
\hline Alluvium & 5549.40 & 38 \\
\hline Sandy soil & 4775.04 & 28 \\
\hline Rocky area & 192.98 & 1 \\
\hline
\end{tabular}

\section{Materials:}

Hardware and software:

Enhanced thematic Mapper Plus (ETM+) Scene (178/51) was used as a base soil map. Soil samples were collected from auger sites and representative profiles.

PC Processor: Pentium R Dual-Core CPU T4300 @ 2.1GHz 2.1 GHz, RAM: 2.00GB, System type: 32-bit operating system.

Scanner genius color page-HRs,30-Bit optical resolution 600*1200 DPI SCSI.

Color printer HP Deskjet (1050 series).

ERDAS Image 8.5 advanced software.

GARMIN 12XL GPS

\section{Methods:}

Reconnaissance survey:

A preliminary reconnaissance survey was conducted to determine the variations among soils of study area. The coordinates of the study area were recorded in a set of GPS (Model GARMIN 12XL.). A stratified soil sampling method was set in order to coverall soil patterns in the area. Then, 15 sites including 3 profiles (A, B and C) and 12 auger sites were selected in different physiographic units for soil sampling. The coordinates of these auger and representative sites were pre-entered in the GPS prior to field work.

\section{Field work:}

At each auger site, approximately 500gof a soil samples was collected from the depths 0-30, 30-60 and 60- $90 \mathrm{~cm}$ using pocket auger. The samples were kept in well labeled plastic bags then transported to the laboratories. The 
tentative locations of three representative soil profile pits were selected to present the different physiographic units. At each soil profile site, a pit $(1.5 \times 1 \times 1.5 \mathrm{~m})$ was dug and approximately $1 \mathrm{~kg}$ of the soil was collected from each genetic horizon/or layer and kept in well labeled plastic bag. Each horizon or layer was then fully described according to the FAO guidelines (FAO, 2006). All soil profile descriptions were entered into the multilingual soil data Base (SDBM plus, FAO, 1995) and the software was used to convert these codes into full profile description. Then the soil representative profiles were classified on their morphological properties according to the American System of soil classification (Keys to Soil Taxonomy, 2014). This classification was later refined by results of laboratory analysis.

\section{Soil analysis}

In the laboratory, soil samples were spread to air dry at room temperature and then ground using wood pestle and mortar, sieved to pass $2 \mathrm{~mm}$ sieves and kept in plastic bags for subsequent analysis. Soil samples from 12 augers and 3 profiles analyzed using standard methods. The gathered data were statistically analyzed and Duncan Multiple Range Test (DMRT) was used for mean separation. Some of the chemical and properties analyzed in the soil samples from representative profile are presented in Table 2.

Table 2: Some soil physical and chemical properties of the soil samples from the representative soil profiles.

\begin{tabular}{|c|c|c|c|c|c|c|c|c|}
\hline \multirow[t]{2}{*}{ Land unit } & \multirow[t]{2}{*}{$\begin{array}{l}\text { Soil samples } \\
\text { and depth } \\
\text { (cm) }\end{array}$} & \multicolumn{2}{|c|}{$\begin{array}{l}\text { Munsell soil color } \\
\text { notation }\end{array}$} & \multicolumn{3}{|c|}{ \%Particle size distribution } & \multirow[t]{2}{*}{$\begin{array}{l}\text { Bulk } \\
\text { density } \\
\left(\mathrm{g} / \mathrm{cm}^{3}\right)\end{array}$} & \multirow[t]{2}{*}{$\begin{array}{l}\text { Texture } \\
\text { class }\end{array}$} \\
\hline & & Moist & Dry & Clay & Silt & Sand & & \\
\hline \multirow[t]{4}{*}{ A } & $0-27$ & 5YR4/1 & 10YR 3/2 & 37.43 & 16.02 & 46.55 & 1.20 & SCL \\
\hline & $27-62$ & 5YR 3/1 & 5YR 5/1 & 45.75 & 16.55 & 37.7 & 1.21 & SC \\
\hline & $62-100$ & $7.5 \mathrm{YR} / 5 / 6$ & $5 Y 5 / 1$ & 67.93 & 19.52 & 12.55 & 1.27 & $\mathrm{C}$ \\
\hline & $100-150$ & 2.5 YR $3 / 2$ & 10 YR $5 / 2$ & 58.55 & 22.65 & 18.8 & 1.23 & $\mathrm{C}$ \\
\hline \multirow[t]{3}{*}{$\mathrm{B}$} & $0-60$ & 5YR $2.5 / 2$ & $10 \mathrm{YR} 4 / 4$ & 48.45 & 50.98 & 0.57 & 1.11 & SC \\
\hline & $60-90$ & $2.5 \mathrm{YR} 4 / 2$ & $10 \mathrm{YR} 5 / 2$ & 18.45 & 33.2 & 48.35 & 1.11 & $\mathrm{~L}$ \\
\hline & $90-150$ & 5YR 3/2 & $7.5 \mathrm{YR} 4 / 2$ & 50.88 & 19.72 & 29.4 & 1.20 & $\mathrm{C}$ \\
\hline \multirow[t]{3}{*}{$\mathrm{C}$} & $0-40$ & 2.5 YR $4 / 4$ & 7.5 YR 5/6 & 15.95 & 4.25 & 79.8 & 1.42 & SL \\
\hline & $40-80$ & 2.5 YR $5 / 8$ & 7.5 YR 5/8 & 18.38 & 4.9 & 76.72 & 1.4 & SL \\
\hline & $80-150$ & 2.5 YR $6 / 6$ & 10YR 6/6 & 18.38 & 5.1 & 76.52 & 1.39 & SL \\
\hline
\end{tabular}

Note: Sandy Clay loam-SCL, Sandy Clay-SC, Clay- C, Silt Clay-SC, Loam- L, Sandy Loam- S

Table 2 (continued)

\begin{tabular}{|c|c|c|c|c|c|c|c|}
\hline L. unit & & pH & $\begin{array}{c}\text { ECe } \\
(\mathrm{ds} / \mathrm{m})\end{array}$ & 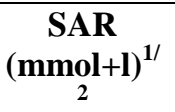 & $\begin{array}{c}\mathrm{CaCO}_{3} \\
(\%)\end{array}$ & $\begin{array}{r}\text { Avai } P \\
(\mathbf{p p m})\end{array}$ & $\begin{array}{l}\text { OM } \\
(\%)\end{array}$ \\
\hline \multirow[t]{4}{*}{$\mathrm{A}$} & 0 - 27 & 8 & 1.25 & 10.98 & 6.41 & 0.67 & 0.11 \\
\hline & $27-62$ & 7.9 & 2.03 & 24.09 & 2.56 & 0.64 & 0.11 \\
\hline & $62-100$ & 8 & 1.24 & 17.27 & 2.56 & 0.67 & 0.11 \\
\hline & $100-150$ & 8 & 0.56 & 17.59 & 2.09 & 0.82 & 0.12 \\
\hline \multirow[t]{3}{*}{ B } & $0-60$ & 6.7 & 0.36 & 2.96 & 0.85 & 0.82 & 0.10 \\
\hline & $60-90$ & 7.3 & 0.36 & 3.5 & 1.45 & 0.69 & 0.11 \\
\hline & $90-150$ & 7.2 & 0.53 & 6.09 & 2.56 & 0.72 & 0.08 \\
\hline \multirow[t]{3}{*}{$\mathrm{C}$} & $0-40$ & 6.4 & 0.59 & 1.55 & 2.56 & 0.67 & 0.10 \\
\hline & $40-80$ & 6.6 & 0.62 & 7 & 2.56 & 0.75 & 0.06 \\
\hline & $80-150$ & 6.9 & 0.26 & 2.27 & 2.14 & 0.67 & 0.07 \\
\hline
\end{tabular}

Land suitability for rainfed agriculture:

In order to evaluate land suitability for rainfed agriculture in the study area, Kevie and El-Tom, (2004) method was applied; the method depends generally on the land qualities. The evaluation was carried out in order to estimate land suitability for rainfed production of field and horticultural crops. The different land qualities that influence soil suitability for rainfed agriculture are rated in a capability index for rain fall (IP) (Table 3.3) using Storie method as in the following equation:

$$
\mathrm{I}=\mathrm{A} \times \mathrm{B} / \mathbf{1 0 0} \times \mathrm{C} / 100 \times \cdots+--\times \mathrm{F} / 100
$$


Where: I - capability (capacity) index (\%) and A, B, C, etc. rating (\%) of the different soil and site properties used in the system. Then capacity index for the different capacity classes of Sys (1991) was used to define the capacity (capability) classes (Table 3).

Table 3:Capacity indexes for the different capacities classes

\begin{tabular}{|c|c|l|c|}
\hline Capacity indexes & Class & \multicolumn{1}{|c|}{ Definition } & Symbol \\
\hline$>80$ & I & Excellent & S1 \\
\hline $60-80$ & II & Suitable & S2 \\
\hline $45-60$ & III & Slightly suitable & S3 \\
\hline $30-45$ & 1V & Almost unsuitable & N1 \\
\hline$<30$ & V & Unsuitable & N2 \\
\hline
\end{tabular}

Source: Sys. (1991).

\section{Crop suitability:}

The suitability of the soils to agricultural crop is assessed by different soils and land characteristics. The characteristics include: the study of the soil, available water resources, climate and vegetation cover. Then soils suitable for agriculture are recognized and crop or group of crops suitable to be grown under the availability of climatic regime are identified. Then the combined effect of all factors is computed mathematically to give the optimal land use. These factors include: soil properties (soil texture, soil depth, depth of ground water, condition of internal drainage, salinity, $\% \mathrm{CaCO}_{3}$, slope, available phosphorous, soil $\mathrm{pH}$ and $\% \mathrm{OC}$ ), climatic factors (precipitation and temperature) and topography (slope). Each factor is given a classification rating from 0 to 100 for each crop. The classification ratings are multiplied to give the suitability or productivity index of the crop or group of crops (Table 4).

Table 4: Land suitability index for agriculture crops

\begin{tabular}{|c|l|}
\hline Suitability index for a crop (average for group of a crop) & \multicolumn{1}{c|}{ Degree of suitability } \\
\hline $80-100$ & Excellent \\
\hline $60-80$ & Goods \\
\hline $40-60$ & Moderate \\
\hline $20-40$ & Poor \\
\hline $0-20$ & Unsuitable \\
\hline
\end{tabular}

Source:Sys, (1991).

\section{RESULTS}

\section{Land suitability for rainfed agriculture:}

The method of land suitability for rainfed was defined according to value of capability (or suitability) index (IP) that was calculated by weighted average for upper $100 \mathrm{~cm}$ of the soil profile for slope, texture, soil depth, $\% \mathrm{CaCO}_{3}$, salinity, sodicity, and drainage. The suitability classes for rainfed agriculture of the study area were identified according to Kevie and El-Tom, (2004). The three units were found to be slightly suitable (S3), unit B and almost unsuitable (N1), units A and C for rainfed agriculture due to presence of moisture availability and chemical fertility limitations (Table 5). 
Table 5: Land suitability of the different soils of the study area for rainfed agriculture:

\begin{tabular}{|llll|}
\hline \multirow{2}{*}{ Land qualities } & \multicolumn{4}{l|}{ Physiographic } & units & \\
\cline { 2 - 4 } & A & B & C \\
\hline Soil moisture availability & 85 & 85 & 85 \\
\hline Chemical fertility & 60 & 60 & 60 \\
\hline Conditions for seedling establishment. & 1 & 1 & 1 \\
\hline Drainage & 85 & 95 & 1 \\
\hline Soil consistence & 1 & 1 & 95 \\
\hline Workability & 95 & 1 & 1 \\
\hline Possibility for mechanization & 1 & 1 & 85 \\
\hline Salinity & 1 & 1 & 1 \\
\hline Sodicity & 85 & 1 & 1 \\
\hline Erosion hazards & 1 & 1 & 1 \\
\hline Depth of ground water & 1 & 1 & 1 \\
\hline Land cover & 1 & 1 & 1 \\
\hline Over all Suitability & $\mathrm{N} 1 *(35.01)$ & S3(48.45) & N1(41.18) \\
\hline Limitations & N1fmd(s) & S3fmd & N1fmp \\
\hline
\end{tabular}

*N1=currently not suitable; $\mathrm{S} 3=$ marginally not suitable

**limitation; $\mathrm{f}=$ fertility; $\mathrm{m}=$ moisture deficit; $\mathrm{d}=$ drainage; $\mathrm{s}=$ salinity

\section{Crop suitability of soils in study area:}

The suitability of the soils to the different crops was determined for field and horticultural crops according to Sys (1993). The crop suitability was determined by matching site conditions with crop requirements with respect to the following site characteristics and soil properties: topography (slope), drainage, physical features (texture, structure), $\mathrm{CaCO}_{3}$ status, soil fertility (soil $\mathrm{pH}$ and organic matter), salinity and climatic (precipitation and temperature) conditions. The suitability for the field and vegetable crops, was divided into suitable, slightly (marginally) suitable and almost unsuitable (Table 6). The major limitations are due to soil texture, moisture availability, organic matter and fertility. However, the suitability of unit B for millet due to good slope, excellent texture, organic matter and soil $\mathrm{pH}$.

Table 6: Overall land suitability for field and vegetable crops in study area:

\begin{tabular}{|lccc|}
\hline Crop type & \multicolumn{3}{c|}{ Land units } \\
\cline { 2 - 4 } & Soil unit A & Soil unit B & Soil unit C \\
\hline Groundnuts & N1 & N1 & N1 \\
\hline Maize & N1 & N1 & N1 \\
\hline Millet & S3 & S2 & S3 \\
\hline Sesame & N1 & S3 & 1 \\
\hline Sorghum & S3 & S3 & N1 \\
\hline Tomato & N1 & N1 & N1 \\
\hline Water melon & N1 & N1 & N1 \\
\hline
\end{tabular}

\section{DISCUSION}

There are no differences in the depth means of $\mathrm{pH}$ in the three units. This is not expected since all the soils have formed under semi-arid climate which means limited moisture in the soil profile and, therefore, there is little water percolating through the profiles $\mathrm{pH}$ values were as follows: $\mathrm{pH}$ of unit $\mathrm{A}>\mathrm{pH}$ of unit $\mathrm{B}>\mathrm{pH}$ of unit $\mathrm{C}$. This could be due to the fact that soils of unit A had resulted from sheet wash erosion which lead to erosion of the surface and formation of a continuous un-cracked surface crust which impedes the infiltration of water. Soils of unit B received extra moisture from wadis draining JabelMarra and therefore, they were relatively more leached and had lower values of $\mathrm{pH}$ than soils of unit $\mathrm{A}$. Whereas soils of unit $\mathrm{C}$ were sandy in texture and with high infiltration rates, therefore, they were more leached during the rainy than the other two soils. Differences between ECe values between soils of units $\mathrm{B}$ and $\mathrm{C}$ on the one hand and those of unit $\mathrm{A}$ on the other could be explained by the same above argument plus the fact that soils of unit $\mathrm{A}$ are heavier in texture than those of the other two units which were relatively more leached. The soils were calcareous to slightly calcareous. This not unexpected for soil that have formed (still are forming) under arid and semi-arid climate. The organic matter was low. This could be explained by the fact that the soils have formed under semi-arid climate with high temperature and low rainfalls which are both 
conducive to the rapid oxidation of any organic matter that might possibly accumulate in the profile. In addition, the vegetational cover is very sparse in the study area because of the semi-arid climate. Also, low O.M contents in cultivated (unit B and C) land could be due to land clearance. This attributed to fact that, cultivation increases soil aeration which enhances decompositions of SOM and most of the percent SOM produced in soils of cultivated land removed with harvest causing for its reduction in values of OC content which in turn an increased in soil bulk density and decreased soils total porosity. This is in agreement with the findings given by Achalu (2012) who stated on the depletion of soil OC in cultivated and grazing land. As expected the available phosphorous was low because of the aridity of the climate. Because the availability phosphorous in most soils of arid and semi-arid climate is generally decline as a result of fixation, abundant crop harvest and erosion. This is same with results that were obtained by Eylachew, (2001) and Dawit et al., (2002) who reported low availability of phosphorous in soils of Ethiopia. Also, this may be attributed to their low inherent fertility and fertility potential. This is in agreement with findings by HTS, (1974) who studied the soil properties in Darfur.

The soils of three units were classified based on American System of soil classification (2014) as Sodic Haplocambids (unit A), Ustic Torrifluvents (unit B) and Typic Torripsamments (unit C). The soils of the three units were found to be slightly suitable (S3), almost unsuitable (N1) and unsuitable (N2) for rainfed agriculture. That was because of presence of some limitations e.g. fertility, low organic matter, texture, drainage, erosion and sodicity. This is in agreement with the findings by Briza et al., (2001), Yasmin (2001) and Abagyeh, et al., (2016) who reported on the land suitability for different crops in different areas grown under rainfed conditions. The soils of unit $\mathrm{B}$ is proved to be the best suitable land for rainfed agriculture, this is because of good slope, excellent texture, soil $\mathrm{pH}$ and depth of soil.

The three units were found to be of different suitability for different crops. This could be due to the fact that the soils of the different units had different characteristics and crops differ in their requirements, therefore, there were different suitabilities of the different units to the crops studied.

The soils of study area were saline, non-sodic (with exception of the soils of unit A) and calcareous to slightly calcareous and low in fertility. The soils of the area were marginally (slightly) suitable for rainfed agriculture although presence of some limitations. The most limiting factors for crop production under rainfed conditions in this area were low fertility, drainage, organic matter and texture limitations.

\section{RECOMMENDATIONS}

The following recommendation can be made:

1. Further studies with respect for soil characterization and land suitability evaluation in rainfed areas should made in order to provide data base for land use planning.

2. Soil reclamation for sodic soil found in unit A of study area should be made by adding organic manure (farmyard and chicken manure) to improve the soil properties (structure, infiltration rate, aeration and water holding capacity and fertility).

3. Deep chisel plowing and terraces establishment should be used in order to improve the soil moisture especially for soils of units A and B in order to trap in the rain water and improve the moisture content of soils.

4. Early maturing and drought resistant crop varieties are recommended to grow under such conditions in order to avoid crop failure, enhance production and improve the socio-economic status in the study area.

5. Soil conservation practices should be applied for soils of unit $\mathrm{C}$ to avoid soil erosion.

6. The study recommended tapping of ground water to avail water for irrigation.

\section{References}

[1] Abagyeh S. O. I., Idoga S., Agber P. I. (2016).Land suitability evaluation for maize (Zea mays) production in selected sites of the Mid- Benue valley, Nigeria. International Journal of Agricultural Policy and Research.

[2] Abdulkadir, A. (1998). Soil types and their management in the southern lake area, Nigeria. Proceedings of the $12^{\text {th }}$ National Irrigation and drainage seminar on irrigation in sustainable agriculture, $14^{\text {th }}-16^{\text {th }}$ April, IAR, ABU, Zaria, Nigeria, pp. 334- 348.

[3] Achalu, C.; Heluf, G., Kibebew, K. and Abi, T., (2012). Status of selected physicochemical properties of soils under different land use systems of Western Oromia, Ethiopia. Journal of Biodiversity and Environmental Sciences (JBES).

[4] Braimoh, A.K. (2000). Land evaluating for sorghum based on Boolean and Fuzzy set methodologies. Nigerian journal of soil sciences. 
[5] Briza, Y., F. Delionardo and A. Spisni, (2001). Land evaluation in the province of Ben Sliman, Morocco, 21st Course Professional Master. Remote Sensing and Natural Resources Evaluation. 10 Nov 2000 -22 June 2001, IAO Florence, Italy.

[6] Dawit S, Fritzsche F, Tekalign M, Lehmann J, Zech W. 2002b.Phosphorus forms and dynamics as influenced by land use changes in the sub-humid Ethiopian highlands. Geoderma.

[7] Eylachew Zewdie, (2001). Study on physical, Chemical and Mineralogical Characteristics of Some vertisols of Ethiopia. Wondimagne Chekol and Engda Mersha (Eds). In: proceeding of the $5^{\text {th }}$ Conference of Ethiopia Society of Soil Science (ESSS). The Ethiopian Society of soil Science (ESSS), Addis Ababa, Ethiopia.

[8] FAO (2006). World Reference Base for Soil Resources 2006: a Framework for International Classification, Correlation and Communication. Rome, Italy.

[9] FAO, (1995). Guidelines; Land Evaluation for Rain fall Agriculture. Soil Resources Management and Conservation Service, land and Water Development Division Rome, FAO Bulletin.

[10] Hunting technical Services L. T. D. (1974). South Darfur land -Use Planning Survey. Development Plan-Annex 1. Soil and Vegetation Resources. Democratic Republic of Sudan.

[11] OgunkunleAo, (1986). Spatial variability of some chemical properties in two mapping units in south Nigeria, Soil survey and evaluation.

[12] Soil survey staff (1993). Soil Survey Manual. Soil Conservation Service U.S Department of Agriculture Handbook 18. U.S. Gove printing office, Washington.

[13] Storie, RE. (1976). Storie Index Soil Rating (revised 1978). Spec. Publ. Div. Agric. Sci. University of California, Berkeley.

[14] Sys C, Ranst V, Debaveye J, Beernaert, F. (1993). Land evaluation Part III, crop requirements. Agricultural Publication No. 7, ITC, Ghent.

[15] Sys, C., E; Van Ranst and Debaveye, J. (1991). Land evaluation, part I: Principles in land evaluation and crop production calculation, General Administration for Development Cooperation, Brussels, Belgium.

[16] Soil Survey Staff. 2014. Keys to soil taxonomy, 12th edition. USDA Natural Resources Conservation Service.

[17] USDA. Soil Taxonomy, (1993). Agric handbook No 463, national soil conservation service (NSCE), (USDA), Washington.

[18] Van der Kevie, W. and O. A. M. El-Tom, (2004). Manual for land Suitability Classification for Agriculture with particular Reference to Sudan. Ministry of Sciences and Technology, Agric. Research and Technology Corporation. Land and Water Research center, Wad-Medani, Sudan.

[19] Yasmina, A., Moulay, A., Najmia, A.M., Enrico, B., Yasmina, B., Paolo Omar, C \& Aldo, D. 2001. Land Evaluation in the province of Bel Slimane, Morocco. Proceedings of $21^{\text {st }}$ Course Professional Master Geomatics and natural Resources Evaluation, Nov.10, 2000 - Jun. 22, 2001, Ministry of Foreign Affairs, Instituto Agronomico PerL'oltremare, Italy, $148 \mathrm{p}$. 